\title{
Beyond Access: Reconceptualizing Digital Identification and Inclusion through the Case
}

\section{of Aadhaar}

\begin{abstract}
India's Aadhaar biometric identification system - the world's largest digital identification scheme which provides unique identification to over 1.2 billion peoplehas become a vibrant archetype of the pursuit of inclusion through technology. However, the notion of inclusion appears to be taken for granted in various studies of Aadhaar, with little problematization of technology's role in realizing its multiple facets. Against this backdrop, we survey conceptualizations of inclusion in the discourses on Aadhaar to understand its facets and underlying assumptions. Drawing on a literature review of studies that link the Aadhaar to inclusion, we show that the dominant discourse equates inclusion to the potential for accessing welfare provisioning, services, or other socioeconomic benefits through the instrumentality of technology. We critique this dominant position of inclusion as narrow, by drawing upon the body of work on social inclusion and human development. We suggest a reconceptualization of digitally enabled social inclusion that attends to higher-level processes and outcomes beyond accesssuch as participation, transformation, empowerment, and emancipation — and articulates technology implications beyond technical-rational instrumentality. We contribute a conceptual framework of digital inclusion that has relevance for other developing countries undergoing digital identification initiatives for inclusion.
\end{abstract}

Keywords: Digital Identification, Inclusion, Aadhaar, Information Systems, Socioeconomic Development, Discourse 


\section{Introduction}

Socioeconomic development is not without winners and losers and the quest for equity remains an ongoing concern. In the developing world, significant numbers of people —up to 1.1 billion or $15 \%$ of the world population (World Bank, 2017) —are unable to reap the benefits of development because they have no means of proving their legal identity in order to benefit from services or otherwise fully engage in socioeconomic activities. This vast population of mostly poor and vulnerable groups (Nemschoff, 2015; Nilekani \& Shah, 2015) are indicative of a systemic 'identity gap' (Gelb \& Metz, 2018) that poses a challenge to developing countries hoping to make progress in human development and not just economic growth.

The implications of identification and the identity gap are far reaching as the World Bank's identification for development (ID4D) program and the Sustainable Development Goals (SDGs) have recognized (United Nations, 2015). ${ }^{1}$ In general, there are two justifications for addressing the identity gap through digital identification systems. Firstly, digital identification allows citizens, particularly marginalized and vulnerable groups who are otherwise invisible to the state and formal organizations to become visible (Scott, 1998), in order for the state to better meet its obligations under the social contract. Secondly, from the perspective of the state, certain developmental hurdles can be linked to the lack of legal identity and absence of national means of unique identification and authentication. Phenomena such as absenteeism and 'ghost' workers on public payrolls in developing countries indirectly drain the public purse and lead to perverse outcomes (Dovlo, 2005; Nafiu, Yalo, \& Aduku, 2016). Other problems such as fraud and leakage in public distribution, as well as inefficient targeting or mistargeting of welfare beneficiaries are directly attributable to the lack of unique identification.

In recent years, all but a handful of developing countries have embarked upon national digital identification schemes. Every country in sub-Saharan Africa have for example

\footnotetext{
${ }^{1}$ SDG target 16.9 aspires to "provide legal identity to all, including through birth registration, by 2030"
} 
implemented or committed to a national ID project (Gelb \& Metz, 2018) with varying levels of success. Of the various digital identification initiatives, none is more noteworthy than India's Aadhaar, which in a mere decade has provided unique digital biometric identification for over 1.2 billion people and brought various public and anti-poverty programs within reach of vulnerable and marginalized groups (Chin, Hennessy, \& Madubuko, 2015; UIDAI, 2012). From the viewpoint of its original mandates - the enrollment of residents, ${ }^{2}$ and application of their unique identification (UID) for service delivery through authentication (UIDAI, 2010) Aadhaar has been a success. There is also evidence that Aadhaar has had enormous developmental impacts by strengthening state capacity and enabling outcomes that would not exist otherwise (Muralidharan, Niehaus, \& Sukhtankar, 2016).

Although the Aadhaar does not by itself guarantee benefits, services, or citizenship (Unique Identification Authority of India (UIDAI), 2012a; Venkatesan, 2013), its real-time identity verification infrastructure was intended to enable effective and efficiently targeted delivery of any goods or services to eligible beneficiaries (Nair, 2018; Nilekani \& Shah, 2015). This is consequential given India's vast and increasing social protection expenditure which increased by about 12\% annually between 1992 and 2012, from $\$ 2$ billion to $\$ 18.3$ billion (Kapur \& Nangia, 2015). The government of India also annually spends $\$ 50$ billion on direct subsidies such as coupons for cooking gas, food items like rice, etc. (Nemschoff, 2015; Nilekani \& Shah, 2015). Such outlays are in line with increasing emphasis on anti-poverty programs and social protection around the world, and recommended policies by the UN and the International Labor Organization for countries to adopt measures that guarantee income security and social services for all (International Labour Organization (ILO), 2014; UN General Assembly, 2012).

\footnotetext{
${ }^{2}$ That is, to collect resident's demographic and biometric data, and generate and assign a UID to each resident
} 
Notwithstanding critiques of the Aadhaar (Abraham, 2018; Ramakumar, 2010; Satpathy, 2017; Srinivasan, Bailur, Schoemaker, \& Seshagiri, 2018), questions remain about how and why inclusion is realized through Aadhaar given that technology by itself is neither good nor bad, neither is it neutral (Kranzberg, 1986). Relatedly, it remains an open question whether another Aadhaar-like system might render equivalent outcomes in those countries that aspire to its ambitions (Raj \& Jain, 2016; Zelazny, 2012). At the heart of these questions is the notion of inclusion and its relationship to digital identity technologies such as the Aadhaar. Various Aadhaar studies have touched upon or assumed the concept of inclusion but there is no study, from our review, that has problematized its various meanings and dimensions from a holistic developmental perspective.

Motivated by these concerns, we conducted an in-depth literature review of studies linking Aadhaar to inclusion in different socioeconomic domains to develop a picture of various conceptualizations of the notion of inclusion and the implications of identification technology. We seek to shed light on the question of how scholars have conceptualized inclusion in the case of Aadhaar and what this might mean for understanding the developmental potential of digital identification projects in developing countries generally.

Next, we present a theoretical framing that draws on a body of work on social inclusion and theory of human development. We then present findings from our in-depth review in the form of discourses of inclusion found in the literature on Aadhaar (details of our review methodology are presented in Appendix 1). We discuss the extant approaches and reconceptualize current understandings of inclusion by suggesting a holistic framework and areas for research on the implications of technology for different dimensions of inclusion. Limitations of our study, along with concluding remarks are then presented. 


\section{Framing inclusion through a human development perspective}

Inclusion is a multifaceted and dynamic concept but can simply be understood as people's ability to fully partake in society and to determine their own destinies (Warschauer, 2003). The notion of inclusion has been formulated through neoliberal ideologies and dates back to the nineteenth century (Gidley, Hampson, Wheeler, \& Bereded-Samuel, 2010). From the neoliberal perspective, inclusion is about devoting resources to human capital development to address challenges of economic growth for global competitiveness (Gidley et al., 2010). In recent years, inclusion has become an important pillar in various social interventions as well as in fields of studies such as Education, Development, Gender and Health.

While inclusion is conceptually linked to exclusion, the former does not mean nonexclusion. Inclusion involves more than the absence of exclusion. In relation to technology however, as revealed through discourses such as Aadhaar's, inclusion has been largely taken for granted and underdeveloped. Next, we discuss dominant dimensions of inclusion and their constituents, with a view to explicating other aspects of inclusion in relation to digital technology.

\section{Dimensions of Inclusion}

Two dimensions of inclusion are frequently discussed in the Information Systems and related literature: social inclusion and economic inclusion. Social inclusion refers to the ability of people to fully partake in society and determine their destinies in terms of who to be, what to do, and how to live (Warschauer, 2003). The object of social inclusion is not only to overcome social exclusion - the denial and inaccessibility of a range of rights as well as lack of social integration of certain groups (Shortall, 2008)—but also to make opportunities available for all groups in society.

As a multidimensional concept, social inclusion covers broad aspects of human life such as work, civic engagement, cultural identity, social interaction as well as access to and utilisation of basic needs like food, education, healthcare and shelter (Selwyn 2002). Different 
factors have been identified as determinants of social inclusion. Gildely et al. (2010) identify access and participation as critical factors. Alam and Imran (2015) further point to choice, affordability and skills. In addition, Phipps (2000) and Selwyn (2002) note the importance of civic and political participation, cultural identity, social interaction and interpersonal networks (Phipps 2000; Selwyn 2002). Although social inclusion can be expanded by digital technology, there is a requirement of individual capability and empowerment because social inclusion is individual oriented (Taket et al., 2009).

Economic inclusion focuses on equal opportunity for individuals to fully participate in work related endeavors and market activities (Bettcher \& Mihaylova, 2015). Economic inclusion is a resource driven dimension of inclusion that focuses on equality of individuals to have opportunities to participate and enjoy benefits of their participation either as employees, entrepreneurs, consumers or citizens (Kim \& Hwang, 2019). As the foundation to attaining basic human needs, economic inclusion can be achieved at two complementary levels: community and individual levels (Bettcher \& Mihaylova, 2015). Economic inclusion at the community level occurs when individuals' access to opportunities such as markets, employment and entrepreneurship is enlarged irrespective of background. On the other hand, economic inclusion at the individual level occurs when people acquire requisite skills to be productive and utilize market opportunities (Bettcher \& Mihaylova, 2015).

Fundamentally, economic inclusion transcends consumption (the capacity to acquire and use goods and services) and production (adding economically valuable activities and outputs) (Burchardt, Le Grand, \& Piachaud, 1999). Thus, for people to be economically included, they must be able to participate in valuable activities that provides them with the ability (income) to purchase goods and services. Though economic inclusion is generally envisaged as access without bias to markets, resources, and opportunities, other equally 
important constituents such as participation and empowerment are required to be fully inclusive (Phipps 2000).

\section{Inclusion Beyond Access}

We identified a set of concepts that have been associated with inclusion in the relevant literature such as access, participation, transformation, empowerment and emancipation. These concepts share the similarity of being individual-centered and seeking to advance the interests of the individual in relation to a collective. For this reason, they are of developmental significance and have also been considered in the literature on socioeconomic development.

Access refers to entry points and abilities for people to engage or receive certain benefits (Kim \& Hwang, 2019). Access can be viewed as a form of capability that allows people to perform certain actions or as availability of opportunities to people (Carnegie, 2010). Access might be the foundation for achieving inclusion but not inclusion in itself. For instance, access to education does not mean education is inclusive since there might be inequalities or other inherent challenges faced by different individuals and groups based on their specific needs and existing capabilities and limitations.

Participation refers to the ability of individuals to actively partake in the set of activities and opportunities they have access to (Farrington \& Farrington, 2005). To participate, therefore, individuals need to have access to requisite resources and skills. And without participation, access does not lead to betterment. Though participation is sometimes taken as a given, socioeconomic and demographic factors such as poverty, education, culture, and gender can present obstacles (Putnam, 1993). For instance, mobile phones might offer access for communication, however, without money to purchase the phone and the requisite technical skills and knowledge to operate the phone, an individual cannot be able to participate in opportunities afforded by the mobile phone. Thus, in the quest to achieve inclusion, participation in addition to access is important. 
Transformation with regards to inclusion can be viewed as fundamental changes to how an individual undertakes certain activities as well as the overall resulting changes in their livelihoods or well-being (Bull, 2013). While transformation might relate to an individual, it can also relate to organizational and societal processes. Organizations and societies undergo transformation if they experience fundamental, and typically positive, changes that are enduring. Such changes might occur from structural shifts that are difficult to undo. While certain changes might be touted in developmental and inclusion initiatives as life-altering, closer inspection reveals them to be fickle and not transformational.

Empowerment and emancipation are additional dimensions of inclusion that are less conceptualized in the literature. Empowerment puts power into the hands of individuals to steer the affairs of their own lives (Andersen \& Siim, 2004). Through empowerment, people are positioned to be liberated from oppressive cultural, socioeconomic, legal and political environments (Parpart, Rai, \& Staudt, 2002). Closely related to empowerment is emancipation which is the freeing of individuals and groups from repressive social and ideological conditions (Alvesson \& Willmott, 1992). Emancipation aims to "eliminate the causes of unwarranted alienation and domination and thereby enhance the opportunities for realizing human potential" (Klein \& Myers, 1999). Given that empowerment and emancipation affirm personal autonomy and freedom from the webs of exclusion, oppression and social injustices, we consider them as the pinnacle of inclusion.

\section{Human development: the capability approach}

In framing inclusion as a development condition that centers on holistic individual well-being, we turn to theory of human development, specifically, Sen's capability approach (1999). The capability approach offers an alternative framing for socioeconomic development by deviating from the narrow economic view of GDP growth to a humanistic development perspective. The capability approach focuses on how capabilities of individuals result in the kind of life they value. At the core of the capability approach are capabilities, functionings, agency and well- 
being. Capability refers to a set of valued choices at the disposal of an individual such as health, freedom and education while functionings represent how people utilise their capabilities (Sen, 1992). However, for individuals to utilise capabilities, they must have freedom and their choices must offer valuable opportunities.

Agency refers to the ability of individuals to pursue what they value while well-being refers to individuals' ability to achieve valuable functionings. Thus, for individuals to achieve valuable well-being, they must first have access to a set of capabilities, freedom and ability to choose capabilities they value and actualise those. Though there may be variety of capabilities, these need to be valued by individuals as a means of well-being. For instance, food as a resource offers the capability for people to eat and be nourished if this food is valued and eaten. However, for people to eat the food, they must have access, freedom and ability to choose the type of food they value.

Given the human development nature of the capability approach, it has been used to assess societal and individual issues such as exclusion, poverty and inability (Robeyns, 2006). Following Zheng and Walsham (2008) as well as Andrade and Doolin (2016), we applied the tenets of the capability approach as a reframing theoretical lens to reconceptualise digital identification and inclusion beyond the narrow view of access. Based on the capability approach, we conceptualise inclusion to include freedom, capabilities, and ability to choose valuable opportunities for well-being (Sen, 1999). Thus, to achieve inclusion through a human development perspective, individuals need to have access to wide range of capabilities as well as freedom and ability to make choices deemed valuable for well-being and utilise selected choices (Alkire, 2005). Although information and communications technologies provide a range of capabilities, theoretical questions remain about how inclusion is realized through them. 
The focus of this study on reframing inclusion beyond access through the digital identification of Aadhaar is a starting point to addressing the narrow view of inclusion. We argue that technologies offer capabilities beyond access which can be utilised for well-being. And as people experience continuous well-being, they achieve human development which we define as constant enlargement in individuals' freedoms and opportunities to satisfy personal needs (Sein \& Harindranath, 2004). Meeting these needs raises a person's level of development to decide their destinies (who to be, what to do, and how to live). As individuals' needs are several, inclusion might be realized if people are able to fully participate in society and attain control over their destinies. But, to achieve well-being and human development, there is a need to have access to certain foundational capabilities to realise other complementary ones. Anchoring on this argument and the capability approach, we posit that access is just the foundation to achieving inclusion as digital technologies provide far reaching capabilities that enable participation, transformation, empowerment and emancipation.

\section{Inclusion through Aadhaar}

An approach for understanding information systems (IS) in their social context is by unpacking the discourses underlying their nature and relation to social action (Lyytinen \& Hirschheim, 1988). By discourses, we refer to "the research approaches stemming from different assumptions on the fundamental nature and consequences of [information systems] innovation" (Avgerou, 2010). Various discourses of inclusion in studies of the Aadhaar are derived from assumptions about the nature and the trajectory of human developmental change induced by digital identification technologies. Two sets of assumptions, in combination, produce four identifiable discourses as follows.

\section{Nature of Aadhaar innovation}

Nature of IS innovation refers to assumptions made about the process and modalities of technology enabled change; whether such change is essentially technical-rational or socially embedded. Technical-rational assumptions - what Khera (2018) calls "technological 
solutionism"- -depicts technologies such as Aadhaar as a tool to address specific socioeconomic, governance, and developmental problems. Such means-ends conceptualization positions technology as a technical fix for a rationally framed problem. Actors are assumed to be rational users of technology and problems are assumed to be knowable, defined, and amenable to technical fixes, if only such fixes are well designed and implemented.

Socially embedded perspectives on the other hand, view change as emerging from complex interactions between digital technologies and its specific socioeconomic, organizational and broader contexts, with outcomes at least in part contingent upon the context of its development and use. From such perspective, the issue of technological change is less about the sophistication of digital artefacts and more about the formative political, cultural, social, and economic dynamics within which such systems are conceived, designed, developed, implemented, and enacted.

\section{Trajectory of Aadhaar innovation}

Trajectory of Aadhaar change points to the unfolding of processes related to inclusionwhether such change occurs radically or incrementally. Radical change occurs fast and brings deep or fundamental change to organizational practices and social structures. It is typically triggered from top-down and involves strategic plans of leaders and centralized bureaucracies aimed at system-wide changes. Examples of Aadhaar related radical change include the introduction of the Aadhaar - first claimed to be voluntary, and later made mandatory in social protection schemes (Nilekani \& Shah, 2015) — as well as Aadhaar-enabled interventions such as demonetization that occurred in November 2016 and took about $86 \%$ of banknotes out of circulation with a presidential decree that took immediate effect (Chauhan, 2017; Masiero, 2017).

Incremental change occurs in a slower fashion and involves minor adjustments to organizational practices and social structures. It is typically generated from bottom-up and involves everyday actions of diverse and dispersed actors who act primarily out of self-interest 
and without recourse to an overarching plan of action. Examples include various innovations developed by and through the various players within the Aadhaar ecosystem (Chin et al., 2015; Sathe, 2014). Other incremental changes involve Aadhaar users and organizations and their local improvisations and adaptations with digital identification.

\section{Aadhaar Inclusion Discourses}

From the two sets of assumptions regarding the nature of Aadhaar change and its trajectory, we identify four discourses related to (1) Access (2) Participation (3) Transformation (4) Empowerment, and Emancipation as illustrated in Figure 1.

\begin{tabular}{|c|c|c|}
\hline $\begin{array}{c}\text { Socially embedded } \\
\text { processes }\end{array}$ & $\begin{array}{l}\text { Participation discourse } \\
\text { Exclusion of deserving } \\
\text { beneficiaries/ inequalities along } \\
\text { existing socioeconomic, gender, } \\
\text { geographic, or class lines } \\
\text { - Redefining nature of citizenship } \\
\text { and entitlements } \\
\text { Unintended harms and potential } \\
\text { risks } \\
\text { Redefining biopolitics, migration } \\
\text { and identity } \\
\end{array}$ & $\begin{array}{l}\text { Empowement/ emancipation } \\
\text { discourse } \\
\text { * Social equality } \\
: \quad \text { New capabilities for the poor } \\
\text { * } \quad \text { High levels of personal, community } \\
\text { resilience (low vulnerability) even in } \\
\text { the absence of government } \\
\text { interventions }\end{array}$ \\
\hline $\begin{array}{c}\text { Technical rational } \\
\text { processes }\end{array}$ & $\begin{array}{l}\text { Access discourse } \\
\text { - Enrollment of } 1.2 \text { billion } \\
\text { people within } 10 \text { years } \\
\text { 'Seeding' of almost all } \\
\text { government welfare } \\
\text { programs } \\
\text { Enabling of public and } \\
\text { private services }\end{array}$ & $\begin{array}{l}\text { Transformation discourse } \\
\text { - } \quad \text { Expanding access to social and } \\
\text { political spaces and systems } \\
\text { - } \quad \text { Improving bureaucratic and social } \\
\text { structures to reduce exclusion } \\
\text { barriers } \\
\text { Bridging divides between } \\
\text { formal//informal socioeconomic } \\
\text { activities }\end{array}$ \\
\hline
\end{tabular}

Figure 1: Discourses of Aadhaar enabled inclusion

Access and participation discourses assume a set of technical rational and socially embedded processes that unfold in a relative short period of time and are radical in nature. Transformation and empowerment/emancipation discourses on the other hand assume Aadhaar change takes long to unfold along technical rational or socially embedded lines. In terms of the relative distribution of the discourses, we find from our sample $(n=48)$ that access and participation 
discourses are the majority $(\mathrm{n}=18, \mathrm{n}=15$ respectively), whereas fewer studies focus on transformation $(\mathrm{n}=13)$ and empowerment/emancipation $(\mathrm{n}=2)$ (Table 1).

\begin{tabular}{|l|l|}
\hline Discourse & Study \\
\hline \multirow{3}{*}{ Access $(\mathrm{n}=18)$} & $\begin{array}{l}\text { Chamuah, 2018, Chaudhuri \& König, 2018, Dandurand, 2019, Drèze et } \\
\text { al., 2017, Ghosh, 2017, Ghosh, 2018, Khera, 2017, Khera, 2018, Kotwal } \\
\text { et al., 2017, Mir U.B et al.,, 2019, Mukherjee \& Sahay, 2019, } \\
\text { Mukhopadhyay et al., 2019, Patankar, 2017, Rao, 2019, Rawat \& } \\
\text { Morris, 2019, Satpathy, 2017, Seetharaman \& Pant, 2018, Srivastava \& } \\
\text { Sharma, 2017 }\end{array}$ \\
\hline Participation (n=15) & $\begin{array}{l}\text { Abraham \& Rajadhyaksha, 2015, Baxi, 2019, Bhatia \& Bhabha, 2017, } \\
\text { Chaudhuri, 2019, Jayal, 2019, Mali \& Avila-Maravilla, 2018, Masiero, } \\
\text { 2016, Masiero, 2018, Nair, 2018, Parikh, 2013, Rao \& Nair, 2019, Sen } \\
\text { et al., 2019, Singh \& Jackson, 2017, Sinha, 2018, Sivamalai, 2013 }\end{array}$ \\
\hline Transformation (n=13) & $\begin{array}{l}\text { Abraham, 2018, Avgerou \& Addo, 2017, Cohen, 2019, Cohen, 2019, } \\
\text { Das \& Masiero S, 2019, Dattani, 2019, Jayaprakash \& Pillai, 2018, } \\
\text { Masiero, 2015, Masiero \& Das, 2019, Mukunthan \& Agarwal, 2019, } \\
\text { Rao, 2019, Sengupta \& Shastri, 2019, Singh, 2019 }\end{array}$ \\
\hline $\begin{array}{l}\text { Empowerment/ } \\
\text { Emancipation (n=2) }\end{array}$ & Breckenridge, 2019,Singh, 2019 \\
\hline
\end{tabular}

\section{Access}

Table 1: Distribution of discourses in literature review sample

Aadhaar's dual mandates of residents' enrollment and application to services through authentication (UIDAI, 2010) are oriented toward providing access through a technical-rational understanding that views the lack of (access to) a unique means of legal identification, and its associated deprivations, as a problem to be addressed with engineering, managerial and economic approaches. In this view, the challenge of inclusion is not due to a lack of political will, but rather, technical solutions to address challenges of coverage and authentication of individual identities (Chamuah, 2018). Aadhaar has been trumpeted in the government narratives as a technical triumph of Indian engineering capabilities, social reformist vision, and formidable leadership (Cohen, 2019; Nilekani \& Shah, 2015).

Such technical rationality aspires to a kind of 'objectivity' that is deemed lacking from previous interventions. For example, UIDAI's official characterization of the Aadhaar (Table 1), distinguished it from previous identification schemes by emphasizing its infrastructuring ambitions and use of a unique 12-digit number instead of profiling information such as caste, 
religion, or language — identifiers that have traditionally provided cleavages for conflicts and discrimination (Solinas, 2018).

\begin{tabular}{|ll|l|}
\hline \multicolumn{2}{|c|}{ Aadhaar is... } & Aadhaar isn't \\
\hline $\begin{array}{l}\text { A 12-digit unique identity for every Indian } \\
\text { individual, including children and infants }\end{array}$ & Just another card \\
\hline 2. & $\begin{array}{l}\text { Enables identification for every resident } \\
\text { Indian }\end{array}$ & $\begin{array}{l}\text { Only one Aadhaar card per family is } \\
\text { enough }\end{array}$ \\
\hline 3. & $\begin{array}{l}\text { Establishes uniqueness for every individual } \\
\text { on the basis of demographic and biometric } \\
\text { information }\end{array}$ & $\begin{array}{l}\text { Collects profiling information such as } \\
\text { caste, religion and language }\end{array}$ \\
\hline 4. & $\begin{array}{l}\text { It is a voluntary service that every resident } \\
\text { can avail irrespective of present } \\
\text { documentation }\end{array}$ & $\begin{array}{l}\text { Mandatory for every Indian resident } \\
\text { who has identification documents }\end{array}$ \\
\hline 5. & $\begin{array}{l}\text { Each individual will be given a single } \\
\text { unique Aadhaar ID number }\end{array}$ & $\begin{array}{l}\text { An individual can obtain multiple } \\
\text { Aadhaar ID numbers }\end{array}$ \\
\hline 6. & $\begin{array}{l}\text { Aadhaar will provide a universal identity } \\
\text { infrastructure that can be used by any } \\
\text { identity-based application (like ration card, } \\
\text { passport, etc.) }\end{array}$ & Aadhaar will replace all other IDs \\
\hline 7. & $\begin{array}{l}\text { UIDAI will give yes/no answer to any } \\
\text { identity authentication queries }\end{array}$ & $\begin{array}{l}\text { UIDAI information will be accessible } \\
\text { to public and private agencies }\end{array}$ \\
\hline
\end{tabular}

Table 1: Official description of the Aadhaar (Unique Identification Authority of India (UIDAI), 2012b)

From an engineering perspective, the design of the Aadhaar is based on platform principles of openness, scalability, and evolvability. The modular design of Aadhaar infrastructure, along with limited functionality in its core module, and open interfaces combined with tightly controlled access and centralized ecosystem governance enabled rapid scalability and overall implementation success (Mukhopadhyay, Bouwman, \& Jaiswal, 2019). Scalability is important because each enrollment requires authentication and biometric deduplication from the vast database in a manner that is efficient and cost-effective. Aside these, the system's achievement of identification uniqueness, security and privacy are deemed as having even higher priority than its scalability (Mir, Kar, Gupta, \& Sharma, 2019).

Studies have considered success factors of the Aadhaar as a technical solution by highlighting the significance of stakeholder alignment (Sivamalai, 2013), effective mobilization and translation of relevant actor-networks (Rawat \& Morris, 2019), openness (Kotwal, Parsheera, \& Kak, 2017), and new organizational arrangements such as 
'governtrepreneurism' (Dattani, 2019). Aadhaar technical rational discourses from an engineering perspective also betray 'social engineering' ambitions of its architects and engineers (Nilekani \& Shah, 2015). In this way, its pretensions toward objectivity are belied by deeply social and political processes (Rao \& Nair, 2019).

For example, by its very design, the engineering choices underpinning the Aadhaar was a response to perceived failed post-colonial Nehruvian socialism that had placed India's poor into abject livelihoods, as well as a break from the entanglements of familial, religious, and caste ties that corrupt proper distribution (Cohen, 2019). Cohen (Cohen, 2019) observes that,

\section{Within the concept-world of Aadhaar, such entanglements prevent the social-yet-to-come, demanding a form of government that can produce a political subject outside of biography, which for the engineers is achieved by conceiving of India as a database, an archive prone to the duplication of its elements, and thus governing India as one would govern a database: by continually 'de-duplicating' it}

Complex social choices and grand societal challenges are reduced to models that data can help to illuminate and ultimately, solve. Data not only enables informational infrastructuring of society but also the datafication of nearly all aspects of life, converting beneficiary populations into 'machine-readable data' (Das \& Masiero, 2019).

\section{Participation}

Participation is the realization of active and ongoing involvement of vulnerable segments of society that are targets of inclusion programs in a manner that is free from discrimination and other barriers. Discourses of participation question the flawed assumption that access to unique identification is, or naturally leads to inclusion. Studies point out that the establishment of a national identification scheme does not of itself guarantee social protection (Bhatia \& Bhabha, 2017). Inclusion is also not a simplistic one-time process that ends with enrolment and seeding but is an ongoing participative process that occurs periodically whenever beneficiaries encounter the state through routine authentication to access entitlements like the public distribution system (PDS) (Singh \& Jackson, 2017). 
Complementary factors such as effective policy interventions and widespread, available access points are also needed to shift access into participation. For example, the JAM trinity intervention - an acronym for Jan Dhan Yojana, a government program to provide bank accounts for all low income families, Aadhaar, and mobile phones - shows how digital identification can be combined with policy and other technological approaches to foster participation of beneficiaries in financial inclusion (Ghosh, 2017).

More broadly, digital identification should be seen as embedded in complex social processes that condition potential outcomes that can be positive or negative (Avgerou \& Addo, 2017). It has been suggested that digitalization of identification and benefit provision presents its own costs and barriers for the poor to access the entitlements of citizenship, leaving them worse off in some cases. The idea that human intermediaries can be eliminated through enablements of digital identification has also been shown to be questionable as the case of local non-profits working with the migrant poor demonstrates (Baxi, 2019). For effective participation of vulnerable groups, the collaborative work practices of human intermediaries are needed to stabilize the technological system, anchoring it to a human infrastructure (Chaudhuri, 2019).

A new set of risks, including the loss of existing assets and expropriation of benefits are further presented by participation through Aadhaar (Abraham \& Rajadhyaksha, 2015). Aadhaar's remains the largest biometric database in the world but does not have a corresponding codification of data protection provisions (Bhatia \& Bhabha, 2017). Importantly, with persistent global cybersecurity threats, the notion of an impregnable and infallible database is an untenable one, and "the question is not if a data breach will ever take place but of "when" will it take place, and whether the data custodian authority will be prepared to anticipate the threat and mitigate the damages" (Avila-Maravilla \& Mali, 2018). 
Moreover, existing socioeconomic and geographic barriers, class and caste, culture, and gender present obstacles to Aadhar participation for many poor and vulnerable. Bhatia and Bhabha (Bhatia \& Bhabha, 2017) observe that,

Geographic enrolment remains uneven, mirroring national patterns of inequality and underprovision with the least well-served populations, regions and states also the least enrolled [...] disproportionate rate of Aadhaar registration among convicted populations in tribal areas against a backdrop of extremely low tribal enrolment overall. One study raises serious questions about the inclusiveness of Aadhaar for urban homeless populations lacking a permanent abode or intact fingerprints [...] questions of how social protection is designed, whether it is targeted, and how a beneficiary is defined require changes which lie outside the realm of improved technology and authentication.

Women are particularly worse off as there appears to be a gender digital divide due to inequalities in education and professional training, assets and access to finance (Sinha, 2018). This is despite that transfers to women of the household through Aadhaar could reduce diversions and improve overall outcomes (Parikh, 2013).

In these ways, the Aadhaar becomes a tool of exclusion that undermines the right to life . For example, in rural Jharkhand where Aadhaar-based biometric authentication is now compulsory for most users of the public distribution system, participation remains a problem due to transaction costs, exclusion problems, and the focusing of the system to fight corruption (Drèze, Khalid, Khera, \& Somanchi, 2017). Aadhaar is said to alter the technical terrain people must navigate to become rights-bearing citizens and adds a new layer of procedures on top of older techniques of recognition (Rao, 2019). Dandurand (Dandurand, 2019) reports that digitalization has enabled the state to exert greater control over rationing practices by rendering them more transparent but that the state's obsession with preventing practices of corruption has hindered, rather than facilitated, access to entitlements for beneficiaries.

\section{Transformation}

Beyond concerns about access and participation, studies have focused on how Aadhaar transforms socioeconomic and organizational spaces. Such initiatives are predicated on the success of widespread access to digital identification which enables economies of scale and 
scope in service provisioning given the resultant large install base. Social and organizational transformation initiatives enabled by the Aadhaar include policy initiatives like the JAM trinity that seek to shift anti-poverty programs to cash transfers. JAM aspires to more than a superficial fix of leakage and aims to fundamentally transform public distribution by bypassing intermediaries and placing cash directly into the accounts of eligible beneficiaries (Saini, S.; Sharma, S.; Gulati, A.; Hussein, J.; Von Braun, 2017).

Such transformational processes might be planned strategic initiatives that once implemented occur through institutionalization of new Aadhaar-enabled processes and deinstitutionalization of previous processes. For example, the PDS which distributed subsidized daily rations like kerosene and rice was transformed into a cash-transfer system through simultaneous processes of Aadhaar institutionalization and deinstitutionalization of the extant state-led subsidy scheme (Masiero \& Prakash, 2019).

Another example is the government's demonetization move that occurred in November 2016 - overtly to combat black money in the country, but covertly, critics argued, to force the bulk of the population to adopt Aadhaar based mobile (Chauhan, 2017). India's Finance Ministry referred to 'demonetisation through digitalisation', claiming that the poor - who hold most of their money in cash money - would be ushered into the digital economy by Aadhaar and related technologies designed for financial inclusion accounts (Chauhan, 2017; Gupta \& Auerswald, 2017). In their study of 200 shop-keepers in Bengaluru and Mumbai, Pal et al., (Pal et al., 2018) reported that the demonetization-induced cash shortages increased digital payment adoption significantly. Furthermore, even among those adversely affected by demonetization, perceptions of the scheme were largely positive given a widespread appreciation for the potential benefits as championed by the government (Pal et al., 2018).

Although the motivations for such initiatives have been questioned, they share a common characteristic of transforming social and economic structures that might eventually 
expand access to those spaces. They also involve bureaucratic improvements that reduce inefficiencies and ineffectiveness and enhance corruption control. In cases like the JAM, they further bridged informal and formal activities like financial access. Analysis shows that JAM cut out the middlemen, reduced leakages and resulted in significant savings the government annually (Mukunthan \& Agarwal, 2019).

\section{Empowerment and Emancipation}

Empowerment is about giving power to the poor rather than simply providing for their subsistence needs. But beyond having power, it is about how such power is used to improve conditions for the poorest of the poor, the neediest, and systemically oppressed groups such as women in society. Empowerment typically unfolds at the local level but is embedded in wider national, regional and global. It involves both outcomes and processes that build the capacities, capabilities, and assets of the poor to become self-reliant and to productively partake in all aspects of the state (Parpart et al., 2002).

So far the literature on Aadhaar inclusion has documented fewer effects of digital identification in empowering the poor, and ultimately, enabling their emancipation from oppressive socioeconomic, legal, political and cultural structures that constrain their selfactualization as full members of society. Aadhaar appears to have strengthened empowerment schemes such as the National Rural Employment Guarantee Act (NREGA), a program that provides up to 100 days of guaranteed, unskilled, waged employment to poor rural households as a way to improve their livelihoods while achieving local development objectives through public works (Khera, 2017). NREGA made significant cash transfers successfully to poor households (Aiyar \& Samji, 2009; Bhattacharya, Pillai, \& Sudarshan, 2010), and in 2012-2013 provided employment for over 4.4 million households (Government of India (Ministry of Rural Development), 2013).

Related to empowerment is emancipation which is the ultimate goal of critical research and critical social action. Emancipation is the freeing of individuals and groups from repressive 
social and ideological conditions (Alvesson \& Willmott, 1992), and aims to "eliminate the causes of unwarranted alienation and domination and thereby enhance the opportunities for realizing human potential" (Klein \& Myers, 1999). Emancipation in relation to technology addresses concerns of alienation (Orlikowski \& Baroudi, 1991), specific rationalities (Levy, Alvesson, \& Willmitt, 2003), and personal and communal identity (Forester, 1992).

From the extant literature, there appears to be no examples of the positive emancipatory potential of Aadhaar. On the contrary, it has been suggested that Aadhaar reifies or creates new

oppressive social structures. Rather than promoting equality, it has been shown that the Aadhaar discourses and related economic policies are biased politically with adverse implications for citizen representation (Sen et al., 2019). Datafying anti-poverty programs through Aadhaar has also been suggested to inflict data injustices on segments of the vulnerable populations it aims to assist (Masiero \& Das, 2019).

Relatedly, digitalization through Aadhaar enables a kind of biopolitics where the state has greater monitoring and control and therefore greater power over citizens (Breckenridge, 2019; Dandurand, 2019). Aadhaar additionally creates "anxieties of recognition" for the poor and vulnerable (Singh, 2019), by for example necessitating physical mobility during enrolment and record updating, which for the disabled and poor can be daunting. Furthermore, when authentication attempts fail, services are denied, and entitled beneficiaries are turned away, the lived "anxieties of recognition" compromise dignity (Singh, 2019).

\section{Towards a reconceptualization of digital identification and inclusion}

The Aadhaar case has provided a rich trove of discourses with which to examine the implications of digital identification systems on inclusion. While, inclusion has been well conceptualized and analysed in fields such as education and gender studies, its use in relation to technology has been largely taken for granted and underdeveloped. Our analysis of the 
Aadhaar case uncovered four discourses that made varying sets of assumptions about the nature and trajectory of sociotechnical change for inclusion.

Our analysis suggests that a majority of studies on the Aadhaar have tended to equate inclusion to 'access' - whether access to unique biometric digital identification or the services and goods its authentication allows. We have suggested that such a view of inclusion is incomplete, if not inaccurate. Not only does the means-ends technical rational view of access ignore complexities of context and social embeddedness but it also ignores the ultimate developmental teleology of inclusion efforts: human development. Human development requires more than technology and the potential instrumental access it might allow. The realization of human development is a complex sociotechnical process that requires everyday top-down and bottom-up enactments under conditions of local and broader social structures and influences. We illustrated with examples from the relatively few studies that have touched on other aspects of inclusion such as participation, transformation, empowerment and emancipation; often in an implicit way that does not adequately problematize the notion of inclusion or its relation to capabilities and enablements of Aadhaar.

Leveraging the capability approach (Sen, 1999), we offer an alternative and richer reconceptualization of inclusion beyond access to include participation, transformation as well as empowerment and emancipation. While we acknowledge that access is an important capability, it is also imperative to highlight other rather consequential capabilities. We argue that for individuals to be socioeconomically included, they must transition from mere access to participate, experience transformation as well as be empowered and emancipated within society. Without experiencing these dimensions of inclusion, individuals are not fully included. Though digital technology may offer capabilities for inclusion, they have only been narrowly considered through the prism of access to the neglect of exploring ways they might enable freedom and valuable functionings (Sen, 1999). 
From our review of the Aadhaar inclusion discourses and informed by our literature framing on inclusion and human development, we synthesize our findings by proposing a framework of the implication of digital identification for inclusion (Figure 2).

\section{A 'Ladder' Framework of Inclusion}

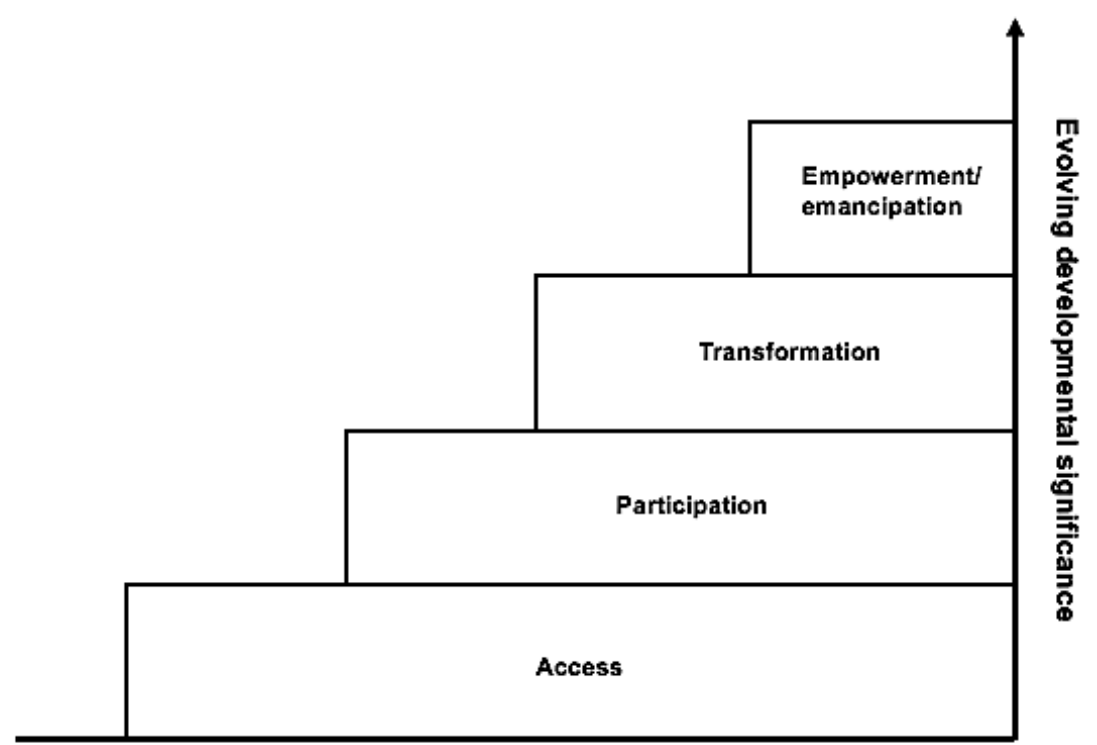

Sociotechnical processes and outcomes enabled by digital identification

Figure 2: A Framework of Digital Identification Enabled Inclusion

We propose that digital-identification-enabled inclusion involves sociotechnical processes and outcomes that progressively evolve in developmental significance from lower level access and participation to higher level transformation, empowerment, and emancipation. Sociotechnical processes might be planned technical rational interventions implemented topdown, or unplanned/emergent everyday socially embedded unfolding from bottom-up. We conceptually depict these 'building blocks' of inclusion as steps on a ladder toward the highest developmental levels of empowerment and emancipation. The metaphor of steps and ladder captured in Figure 2 serves to emphasize that the four dimensions of inclusion are hierarchical from a developmental standpoint, and might also be loosely path dependent (higher level steps build upon lower level ones).

For example, in the case of Aadhaar, empowerment and emancipation depend upon transformations in social structures and spaces; transformation depends upon active and 
widespread participation of various stakeholders; and participation would not be possible without foundational widespread access to UIDs and associated programs. While Figure 2 is depicted as static for simplification, there is dynamism in the unfolding of digital inclusion. Each step might be conceived as both a process and an outcome and while the ultimate goal of inclusion interventions might be empowerment and emancipation, even these are not ends in themselves but ongoing processes that must be realized under constraints of local and broader social contexts.

\section{Conclusion}

Through its considered open and lean architecture, participative implementation, and widespread acceptance, the Aadhaar has defied an important caution from the standpoint of development: the tendency of large centralized government led projects to fail (Scott, 1998). In doing so, it has shown promise in making a difference in the lives of the vulnerable and poor. It's main promise of inclusion — a significant leap from a socioeconomic perspectivehas however not been adequately interrogated from an empirical and intellectual standpoint. Which is not to suggest that Aadhaar has not been studied, nor its claims to inclusion questioned. Rather, the very notion of inclusion has not been adequately conceptualized in relation to the capabilities and affordances of digital identification systems like the Aadhaar, nor from a human development perspective.

This study has taken up this problem by reviewing the extant literature on Aadhaar inclusion to map out their set of discourses and main assumptions. We have further situated such discourses in the context of what is known from a diverse body of social science literature on inclusion and human development to contribute a framework for better understanding the implication of digital identification in inclusion. Our framework makes a number of contributions. Conceptually, it shifts attention beyond a dominant, yet simplistic understanding that equates inclusion to access. Empirically, it serves to remind of higher-level but 
understudied aspirations such as transformation, empowerment, and emancipation that inclusion programs involving digital identification technologies might enable in the pursuit of human development. Theoretically, it suggests a focus on complex sociotechnical processes that condition digital identity schemes for inclusion by showing the thinness of the technical rational framing, and the embeddedness of processes and outcomes. It further raises questions about how scholars might theorize the expansive and complex implications of digital identification for various dimensions of inclusion, beyond a thin instrumental conception of technology

As in the example of the Aadhaar, digital identification artefacts and systems have occasioned profound organizational, economic, political and social reforms that have reinforced to drive inclusion programming on a large scale in a relatively short period. While such change has not been without conflict, criticism, and agitation, it is clear that Aadhaar has come to stay. The challenge therefore may be to critically examine and engage with "how Aadhaar can be made to work [better] in practice while supporting broader development objectives, rather than arguing whether Aadhaar is inherently good or bad" (Mukherjee, 2019). Our study is limited by the sole focus on Aadhaar, which it might be argued is an exception rather than the norm. However, we suggest that Aadhaar is an important revelatory case that can usefully illuminate the path of similar projects in other developing countries. Future studies may explore other digital identification projects and inclusion to extend understanding. 


\section{References}

Abraham, I. 2018. Prehistory of Aadhaar : Body, Law , and Technology as Postcolonial Assemblage. East Asian Science, Technology and Society: An International Journal, 12(4): 377-392.

Abraham, I., \& Rajadhyaksha, A. 2015. State Power and Technological Citizenship in India: From the Postcolonial to the Digital Age. East Asian Science, Technology and Society, 9(1): $65-85$.

Aiyar, Y., \& Samji, S. 2009. Transparency and Accountability in NREGA: A Case Study of Andhra Pradesh. Accountability Initiative Working Paper, vol. 1.

Alam, K., \& Imran, S. 2015. The digital divide and social inclusion among refugee migrants: A case in regional Australia. Information Technology and People, 28(2): 344-365.

Alkire, S. 2005. Why the Capability Approach? Journal of Human Development, 6(1): 115135.

Alvesson, M., \& Willmott, H. 1992. On the Idea of Emancipation in Management and Organization Studies. The Academy of Management Review, 17(3): 432-464.

Andersen, J., \& Siim, B. 2004. The Politics of Inclusion and Empowerment — Gender, Class and Citizenship. The Politics of Inclusion and Empowerment. https://doi.org/10.1057/9781403990013_1.

Andrade, A. D., \& Doolin, B. 2016. Information and communication technology and the social inclusion of refugees. MIS Quarterly: Management Information Systems, 40(2): $405-416$.

Avgerou, C. 2010. Discourses on ICT and Development. Discourses on ICT and Development, 6(3): 1-18.

Avgerou, C., \& Addo, A. 2017. Developmental Effects of the Digital Revolution. In R. Galliers \& M.-K. Stein (Eds.), Critical Perspectives on Business and Management: Management Information Systems. Routledge.

Avila-Maravilla, M., \& Mali, N. 2018. Convergence or Conflict ? Digital Identities vs . Citizenship Rights : Case Study of Unique Identification Number, Aadhaar, in India. Proceedings of the 11th International Conference on Theory and Practice of Electronic Governance, 443-448.

Baxi, P. 2019. Technologies of Disintermediation in a Mediated State : Civil Society Organisations and India' s Aadhaar Project Technologies of Disintermediation in a Mediated State : Civil Society Organisations and India's Aadhaar Project. South Asia: 
Journal of South Asian Studies, 42(3): 554-571.

Bettcher, K. E., \& Mihaylova, T. 2015. Economic Inclusion: Leveraging Markets and Entrepreneurship to Extend Opportunity. https://doi.org/10.2307/j.ctt1tg5gq1.14.

Bhatia, A., \& Bhabha, J. 2017. India's Aadhaar scheme and the promise of inclusive social protection. Oxford Development Studies, 45(1): 64-79.

Bhattacharya, R., Pillai, M., \& Sudarshan, R. 2010. The NREGA and rural women in poverty: Entitlements, issues and emerging concerns. In D. Lawson, D. Hulme, I. Matin, \& K. Moore (Eds.), What Works for the Poorest? Poverty Reduction Programmes for the World's Extreme Poor. Warwickshire: Practical Action.

Breckenridge, K. 2019. Lineaments of Biopower : The Bureaucratic and Technological Paradoxes of Aadhaar. South Asia: Journal of South Asian Studies, 42(3): 606-611. Bull, B. 2013. Social Movements and the 'Pink Tide' Governments in Latin America: Transformation, Inclusion and Rejection. Democratization in the Global South: 75-99. Burchardt, T., Le Grand, J., \& Piachaud, D. 1999. Social exclusion in Britain 1991-1995. Social Policy and Administration, 33(3): 227-244.

Carnegie, M. 2010. Living with difference in rural Indonesia: What can be learned for national and regional political agendas? Journal of Southeast Asian Studies, vol. 41. University of Portsmouth Library. https://doi.org/10.1017/S0022463410000263. Chamuah, A. 2018. For a Sociology of Aadhaar. Contributions to Indian Sociology, 52(3): $343-347$.

Chaudhuri, B. 2019. Paradoxes of Intermediation in Aadhaar: Human Making of a Digital Infrastructure Paradoxes of Intermediation in Aadhaar : Human Making of a Digital Infrastructure. South Asia: Journal of South Asian Studies, 42(3): 572-587.

Chauhan, C. 2017. How Modi's demonetisation move boosted the number of Aadhaar accounts. Hindustan Times.

Chin, R., Hennessy, G., \& Madubuko, T. 2015. India' s Aadhaar Project: The Unprecedented and Unique Partnership for Inclusion. Journal of Administrative Science, 12(1): 1-16.

Cohen, L. 2019. The 'Social' De-Duplicated: On the Aadhaar Platform and the Engineering of Service. South Asia: Journal of South Asian Studies, 42(3): 482-500.

Dandurand, G. 2019. When Biopolitics Turn Digital : Transparency, Corruption, and Erasures from the Infrastructure of Rationing in Delhi. Political and Legal Anthropology Review, 42(2): 268-282.

Das, S., \& Masiero, S. 2019. The Datafication of Anti-Poverty Programmes. 
Dattani, K. 2019. “ Governtrepreneurism ” for good governance: The case of Aadhaar and the India Stack, (July): 1-9.

Dovlo, D. 2005. Wastage in the health workforce : some perspectives from African countries. Human Resources for Health, 3(6): 1-9.

Drèze, J., Khalid, N., Khera, R., \& Somanchi, A. 2017. Aadhaar and Food Security in Jharkhand: Pain without Gain? Economic \& Political Weekly, 52(50).

Farrington, J., \& Farrington, C. 2005. Rural accessibility, social inclusion and social justice: Towards conceptualisation. Journal of Transport Geography, 13(1 SPEC. ISS.): 1-12.

Forester, J. 1992. Critical ethnography: on fieldwork in a Habermasian way. In M. Alvesson \& H. Willmott (Eds.), Critical Management Studies. London: Sage.

Gelb, A., \& Metz, A. 2018. Identification Revolution: Can Digital ID Be Harnessed for Development? Center for Global Development.

Ghosh, S. 2017. Financial inclusion, biometric identification and mobile : unlocking the JAM trinity. International Journal of Development Issues, 16(2): 190-213.

Gidley, J., Hampson, G., Wheeler, L., \& Bereded-Samuel, E. 2010. Social inclusion: Context, theory and practice. The Australasian Journal of University-Community Engagement, 5(1): 6-36.

Government of India (Ministry of Rural Development). 2013. 'DMU Report' - The

Mahatma Gandhi National Rural Employment Guarantee Act.

Gupta, A., \& Auerswald, P. 2017. How India Is Moving Toward a Digital-First Economy. Harvard Business Review.

International Labour Organization (ILO). 2014. World social protection report. Geneva.

Kapur, D., \& Nangia, P. 2015. Social protection in India: A welfare state sans public goods? India Review, 14: 73-90.

Khera, R. 2017. Impact of Aadhaar in Welfare Programmes. SSRN. https://doi.org/10.2139/ssrn.3045235.

Khera, R. 2018. The Aadhaar debate: Where are the sociologists ? Contributions to Indian Sociology, 52(3): 336-342.

Kim, K. M., \& Hwang, J. H. 2019. Exploring gaps in the online economic inclusion of persons with disabilities in Korea. Information Communication and Society, 22(4): $570-581$.

Klein, H., \& Myers, M. 1999. A set of principles for conducting and evaluating interpretive field studies in information systems. MIS Quarterly, 23(1): 67-93.

Kotwal, V., Parsheera, S., \& Kak, A. 2017. OPEN DATA \& DIGITAL IDENTITY : 
LESSONS FOR AADHAAR. Proceedings of the 2017 ITU Kaleidoscope Academic Conference: Challenges for a Data-Driven Society, ITUK 2017.

Kranzberg, M. 1986. Technology and History: Kranzberg's Laws. Technology and Culture, 27(3).

Levy, D., Alvesson, M., \& Willmitt, H. 2003. Critical approaches to strategic management. In M. Alvesson \& H. Willmott (Eds.), . London: Sage.

Lyytinen, K., \& Hirschheim, R. 1988. Information systems as rational discourse: an application of Habermas's theory of communicative action. Scandinavian Journal of Management, 4(1-2): 19-30.

Masiero, S. 2017. Institutional Repository New routes to cashlessness ? ICTs , demonetisation, and the Indian informal economy. Development Studies Association Conference: Sustainability interrogated: societies, growth, and social justice (DSA 2017).

Masiero, S., \& Das, S. 2019. Datafying anti-poverty programmes : implications for data justice. Information, Communication \& Society, 22(7): 916-933.

Masiero, S., \& Prakash, A. 2019. ICT in social protection schemes: deinstitutionalising subsidy-based welfare programmes. Information Technology \& People.

Mir, U. B., Kar, A. K., Gupta, M. P., \& Sharma, R. S. 2019. Prioritizing Digital Identity Goals - The Case Study of Aadhaar in India. Springer International Publishing. https://doi.org/10.1007/978-3-030-29374-1.

Mukherjee, A. 2019. Sinking Under Its Own Weight : Case of Aadhaar Mediated Entitlements in India, vol. 2. Springer International Publishing. https://doi.org/10.1007/978-3-030-18400-1.

Mukhopadhyay, S., Bouwman, H., \& Jaiswal, M. P. 2019. An open platform centric approach for scalable government service delivery to the poor: The Aadhaar case. Government Information Quarterly, 36(3): 437-448.

Mukunthan, A., \& Agarwal, G. 2019. JAM : A Digital , Economic \& Social Revolution. 12th International Conference on Theory and Practice of Electronic Governance (ICEGOV2019).

Muralidharan, K., Niehaus, P., \& Sukhtankar, S. 2016. Building state capacity: Evidence from biometric smartcards in India. American Economic Review, 106(10): 2895-2929. Nafiu, A., Yalo, M., \& Aduku, D. 2016. Assessment of the Variations of Ghost Employee Fraud in Nigeria: 2008-2015. European Journal of Business and Management, 8(24): 1-10. 
Nair, V. 2018. An eye for an I : recording biometrics and reconsidering identity in postcolonial India. Contemporary South Asia, 26(2): 143-156.

Nemschoff, M. 2015, February. Architecting the World's Largest Biometric Identity System: The Aadhaar Experience. Converge Blog.

Nilekani, N., \& Shah, V. 2015. Rebooting India: Realizing a Billion Aspirations. Penguin Books.

Orlikowski, W., \& Baroudi, J. 1991. Studying information technology in organizations: Research approaches and assumptions. Information Systems Research.

Pal, J., Chandra, P., Kameswaran, V., Parameshwar, A., Joshi, S., et al. 2018. Digital Payment and Its Discontents: Street Shops and the Indian Government's Push for Cashless Transactions. Proceedings of the 2018 CHI Conference on Human Factors in Computing Systems.

Parikh, K. 2013. Right to Food and Foodgrain Policy. Economic \& Political Weekly, xlviii(11): 23-27.

Parpart, J., Rai, S., \& Staudt, K. 2002. Rethinking Empowerment : Gender and Development in a Global/Local World.

Phipps, L. 2000. New Communications Technologies: A Conduit for Social Inclusion, Information, Communication \& Society, 3(1): 39-68.

Putnam, R. D. 1993. The Prosperous Community. The American Prospect, 4(13): 1-11. Raj, A., \& Jain, U. 2016. Aadhaar goes global, finds takers in Russia and Africa. Live Mint. Ramakumar, R. 2010. The Huge UID Project in India: A Sceptical Note. In A. Kumar \& D. Zhang (Eds.), Ethics and Policy of Biometrics. Springer.

Rao, U. 2019. Population Meets Database : Aligning Personal, Documentary and Digital Identity in Aadhaar-Enabled India. South Asia: Journal of South Asian Studies, 42(3): $537-553$.

Rao, U., \& Nair, V. 2019. Aadhaar: Governing with Biometrics. South Asia: Journal of South Asian Studies, 42(3): 469-481.

Rawat, P., \& Morris, J. 2019. The Global and the Local : Tracing the Trajectory of the Largest Biometric Identity Program. Politics \& Policy, 47(6): 1066-1094.

Robeyns, I. 2006. The capability approach in practice. Journal of Political Philosophy, 14(3): 351-376.

Saini, S.; Sharma, S.; Gulati, A.; Hussein, J.; Von Braun, J. 2017. Indian food and welfare schemes: Scope for digitization towards cash transfers. Discussion Papers on Development Policy No. 241. Bonn: ZEF Center for Development Research. 
Sathe, V. 2014. Managing Massive Change: India's Aadhaar, the World's Most Ambitious ID Project. InnovationsJ, 9(1): 85-111.

Satpathy, T. 2017. The Aadhaar : "Evil” Embodied as Law. Health Technology, 7: 469487.

Scott, J. 1998. Seeing Like a State: How Certain Schemes to Improve the Human Condition Have Failed. New Haven and London: Yale University Press.

Sein, M. K., \& Harindranath, G. 2004. Conceptualizing the ICT artifact: Toward understanding the role of ICT in national development. Information Society, 20(1): 1524.

Selwyn, N. 2002. E-stablishing an inclusive society? Technology, social exclusion and UK government policy making. Journal of Social Policy, 31(1): 1-20.

Sen. 1999. Development as Freedom. Oxford: Oxford University Press.

Sen, A. 1992. Inequality reexamined. Oxford: Oxford University Press.

Sen, A., Ghatak, D., Kumar, K., Khanuja, G., Gupta, M., et al. 2019. Studying the Discourse on Economic Policies in India Using Mass Media, Social Media, and the Parliamentary Question Hour Data. Proceedings of the 2019 Conference on Computing and Sustainable Societies.

Shortall, S. 2008. Are rural development programmes socially inclusive? Social inclusion, civic engagement, participation, and social capital: Exploring the differences. Journal of Rural Studies, 24(4): 450-457.

Singh, P. 2019. Aadhaar and data privacy : biometric identification and anxieties of recognition in India. Information, Communication \& Society, 0(0): 1-16.

Singh, R., \& Jackson, S. J. 2017. From Margins to Seams : Imbrication , Inclusion , and Torque in the Aadhaar Identification Project. Conference on Human Factors in Computing Systems - Proceedings.

Sinha, S. 2018. Gender Digital Divide in India: Impacting Women's Participation in the Labour Market. In NILERD (Ed.), Reflecting on India's Development. Singapore: Springer.

Sivamalai, L. 2013. Using the Lens of " Social Construction of Technology" to Understand the Design and Implementation of Aadhaar ( UID ) Project, (Id): 633638.

Solinas, P. 2018. Uniqueness, ubiquity, authenticity; the expanding demosfphere of egos: Notes for discussion. 25th European Conference on South Asian Studies.

Srinivasan, J., Bailur, S., Schoemaker, E., \& Seshagiri, S. 2018. The Poverty of Privacy: 
Understanding Privacy Trade-Offs From Identity Infrastructure Users in India. International Journal of Communication, 12: 1228-1247.

Taket, A., Crisp, B. R., Nevill, A., Lamaro, G., Graham, M., et al. 2009. Theorising social exclusion. Theorising Social Exclusion. https://doi.org/10.4324/9780203874646.

UIDAI. 2010. UIDAI Strategy Overview: Creating a Unique Identity Number for every Resident in India.

UIDAI. 2012. Aadhaar Enabled Service Delivery.

UN General Assembly. 2012. The future we want. New York.

Unique Identification Authority of India (UIDAI). 2012a. Features of the UIDAI Model. Aadhaar Technology.

Unique Identification Authority of India (UIDAI). 2012b. Role of Biometric Technology in Aadhaar Enrollment. New Delhi.

United Nations. 2015. Sustainable Development Goals. Goal 16: Promote just, peaceful, and inclusive societies.

Venkatesan, J. 2013, September. Don't tie up benefits to Aadhaar,court tells center. The Hindu. New Delhi.

Warschauer, M. 2003. Technology and Social Inclusion: Rethinking the Digital Divide. London: MIT Press. https://doi.org/10.1086/381987.

World Bank. 2017. Identification for Development Global Dataset.

Zelazny, F. 2012. The Evolution of India's UID Program: Lessons Learned and Implications for Other Developing Countries. no. 008.

Zheng, Y., \& Walsham, G. 2008. Inequality of what? Social exclusion in the e-society as capability deprivation. Information Technology and People, 21(3): 222-243. 


\section{Appendices}

\section{Appendix 1: Details of research method}

To understand the discourse on digital identification and inclusion through the case study of Aadhaar, we conducted a literature review of existing research. Specifically, our research method went through four distinctive steps: (1) defining the review scope, (2) literature search, (3) literature selection and (4) literature analysis.

Defining the review scope

In this step, we defined the scope of the review by establishing our boundaries. Before, establishing the scope of this paper, we performed and initial search using the keyword "Aadhaar" in Scopus, Web of Science, AIS Library and Google Scholar to have a better understanding of the breath of studies and their focus. We selected these databases because they cover a significant number of social sciences, management and information systems journals. Based on the result of the initial search, we defined our scope to focus on only peerreviewed journal and conference articles as well as book chapters. Given our aim of investigating the inclusion aspect of Aadhaar and the need to conduct a quality review (Webster \& Watson, 2002), we also decided to not to consider pure engineering articles in addition to book reviews, books, blog, newsletters, editorials, non-peer review articles, articles not in English as well as working papers. In lieu of the initial search result, we also defined our search terms to include different variations and combination of these keywords containing the keywords "Aadhaar", “inclusion”, “exclusion”, “poor”, "social protection”, "marginalised”, “access", "vulnerable" and "JAM".

\section{Literature search}

Using the defined keywords in step 1, we conducted the main search in three databases: Scopus, Web of Science, AIS Library and supplemented these searches with Google Scholar. We conducted the literature search on the abstract, keywords, and title using the advance search feature of the databases to retrieve only relevant articles. We iteratively searched each database 
(our last search was on $3^{\text {rd }}$ January 2020) using different variations and combinations of the defined keyword (e.g. Aadhaar AND (inclu* OR "exclu*" OR poor OR marginal* OR vulnerable OR "social protection" OR access). From each search result, we exported the list of articles to an Excel master file. Our search from Scopus had 87 article hits, Web of Science 32 and AIS Library 7 hits. We also performed forward searches on articles that had been cited by other studies and this led to the discovery of 6 more articles. In all, a total of 132 articles were collated for evaluation and inclusion in the review. The next subsection provides details of the literature selection process.

\section{Literature selection}

In line with our inclusion and exclusion criteria, we manually reviewed the collated articles to determine their fit with the scope of the review. We reviewed the title, abstract, and keywords of each article in our collated list to determine the focus and fit with our review scope. Articles that did not meet our inclusion criteria were discarded. For instance, pure engineering articles that developed systems, models or framework based on Aadhaar were discarded as they did not discuss inclusion or other "soft" issues. Also, we removed articles that listed Aadhaar as a keyword or as an example in the abstract without further discussion in the main text. Next, we filter the collated list for duplicates as a significant number of articles from Scopus were also indexed in Web of Science. After applying all our inclusion and exclusion criteria, we had a total of 48 highly relevant articles as the final corpus. We proceeded to download the PDF of the articles selected for further reading and analysis.

\section{Literature Analysis}

In this last step, we performed the literature analysis in two phases: (1) descriptive and detailed discourse analysis. For the descriptive analysis, we derived meta data on each article included in the article on elements such as author(s), title, publication outlet, publication year, publication outlet type (e.g., journal or conference proceedings), context of study, level of 
analysis, theoretical foundation, research method and research approach. Some of these data points are presented in Appendix 2.

In terms of the detailed discourse analysis, we followed Webster and Watson (2002) concept-centric approach to unravel discussions on Aadhaar and inclusion. After iteratively reading and coding the articles, we derived four main concepts as discourses on Aadhaar and inclusion. As presented in Table A1, each paper was analysed and classified under access, participation, transformation, empowerment and emancipation or a combination of these concepts. Based on this analysis, we were able to identify dominant discourses and associated nuances as a foundation for our inclusion ladder framework.

Table A1: Concept-Centric

\begin{tabular}{|c|c|c|c|c|}
\hline Article & \multicolumn{3}{|c|}{ Concepts } \\
\hline & Access & Participation & Transformation & Empowerment and Emancipation \\
\hline 1 & & $\mathbf{X}$ & & $\mathbf{X}$ \\
\hline 2 & $\mathbf{X}$ & & $\mathbf{X}$ & $\mathbf{X}$ \\
\hline 3 & & & & \\
\hline 4 & & $\mathbf{X}$ & & \\
\hline
\end{tabular}

\section{References}

Webster, J., \& Watson, R. T. 2002. Analysing the Past to Prepare for the Future: Writing a Literature Review. MIS Quarterly, 26(2): xii-xxiii.

\section{Appendix 2: List of works reviewed}

\begin{tabular}{|c|c|c|c|}
\hline Authors & Year & Title & Publication Outlet \\
\hline 1. Abraham I. & 2018 & $\begin{array}{l}\text { Prehistory of Aadhaar: Body, law, and technology } \\
\text { as postcolonial assemblage }\end{array}$ & $\begin{array}{l}\text { East Asian Science, } \\
\text { Technology and Society }\end{array}$ \\
\hline $\begin{array}{l}\text { 2. Abraham I., } \\
\text { Rajadhyaksha A. }\end{array}$ & 2015 & $\begin{array}{l}\text { State power and technological citizenship in India: } \\
\text { From the postcolonial to the digital age }\end{array}$ & $\begin{array}{l}\text { East Asian Science, } \\
\text { Technology and Society }\end{array}$ \\
\hline $\begin{array}{l}\text { 3. Avgerou C., Addo } \\
\text { A. }\end{array}$ & 2017 & The developmental effects of the digital revolution & $\begin{array}{l}\text { The Routledge Companion } \\
\text { to Management Information } \\
\text { Systems }\end{array}$ \\
\hline 4. Baxi, P & 2019 & $\begin{array}{l}\text { Technologies of Disintermediation in a Mediated } \\
\text { State: Civil Society Organisations and India's } \\
\text { Aadhaar Project }\end{array}$ & $\begin{array}{l}\text { South Asia: Journal of South } \\
\text { Asian Studies }\end{array}$ \\
\hline $\begin{array}{l}\text { 5. Bhatia A., Bhabha } \\
\text { J. }\end{array}$ & 2017 & $\begin{array}{l}\text { India's Aadhaar scheme and the promise of } \\
\text { inclusive social protection }\end{array}$ & $\begin{array}{l}\text { Oxford Development } \\
\text { Studies }\end{array}$ \\
\hline 6. Breckenridge $\mathrm{K}$. & 2019 & $\begin{array}{l}\text { Lineaments of biopower: The bureaucratic and } \\
\text { technological paradoxes of Aadhaar }\end{array}$ & $\begin{array}{l}\text { South Asia: Journal of South } \\
\text { Asia Studies }\end{array}$ \\
\hline 7. Chamuah A. & 2018 & For a Sociology of Aadhaar & $\begin{array}{l}\text { Contributions to Indian } \\
\text { Sociology }\end{array}$ \\
\hline 8. Chaudhuri B. & 2019 & $\begin{array}{l}\text { Paradoxes of intermediation in Aadhaar: Human } \\
\text { making of a digital infrastructure }\end{array}$ & $\begin{array}{l}\text { South Asia: Journal of South } \\
\text { Asia Studies }\end{array}$ \\
\hline $\begin{array}{l}\text { 9. Chaudhuri B., } \\
\text { König L. }\end{array}$ & 2018 & $\begin{array}{l}\text { The Aadhaar scheme: a cornerstone of a new } \\
\text { citizenship regime in India? }\end{array}$ & Contemporary South Asia \\
\hline
\end{tabular}




\begin{tabular}{|c|c|c|c|}
\hline 10. Cohen L. & 2019 & India as database: Response to Reetika Khera & $\begin{array}{l}\text { Contributions to Indian } \\
\text { Sociology }\end{array}$ \\
\hline 11. Cohen, $\mathrm{L}$ & 2019 & $\begin{array}{l}\text { The 'Social' De-Duplicated: On the Aadhaar } \\
\text { Platform and the Engineering of Service }\end{array}$ & $\begin{array}{l}\text { South Asia: Journal of South } \\
\text { Asian Studies }\end{array}$ \\
\hline 12. Dandurand G. & 2019 & $\begin{array}{l}\text { When Biopolitics Turn Digital: Transparency, } \\
\text { Corruption, and Erasures from the Infrastructure of } \\
\text { Rationing in Delhi }\end{array}$ & $\begin{array}{l}\text { Political and Legal } \\
\text { Anthropology Review }\end{array}$ \\
\hline 13. Das S., Masiero S. & 2019 & $\begin{array}{l}\text { The datafication of anti-poverty programmes: } \\
\text { Evidence from the public distribution system in } \\
\text { Karnataka }\end{array}$ & $\begin{array}{l}\text { ACM International } \\
\text { Conference Proceeding } \\
\text { Series }\end{array}$ \\
\hline 14. Dattani K. & 2019 & $\begin{array}{l}\text { "Governtrepreneurism" for good governance: The } \\
\text { case of Aadhaar and the India Stack }\end{array}$ & Area \\
\hline $\begin{array}{l}\text { 15. Drèze J., Khalid } \\
\text { N., Khera R., } \\
\text { Somanchi A. }\end{array}$ & 2017 & $\begin{array}{l}\text { Aadhaar and food security in Jharkhand: Pain } \\
\text { without gain? }\end{array}$ & $\begin{array}{l}\text { Economic and Political } \\
\text { Weekly }\end{array}$ \\
\hline 16. Ghosh S. & 2017 & $\begin{array}{l}\text { Financial inclusion, biometric identification and } \\
\text { mobile: unlocking the JAM trinity }\end{array}$ & $\begin{array}{l}\text { International Journal of } \\
\text { Development Issues }\end{array}$ \\
\hline 17. & 2018 & $\begin{array}{l}\text { Biometric identification, financial inclusion and } \\
\text { economic growth in India: does mobile penetration } \\
\text { matter? }\end{array}$ & $\begin{array}{l}\text { Information Technology for } \\
\text { Development }\end{array}$ \\
\hline 18. Jayal N.G. & 2019 & Reconfiguring citizenship in contemporary India & $\begin{array}{l}\text { South Asia: Journal of South } \\
\text { Asia Studies }\end{array}$ \\
\hline $\begin{array}{l}\text { 19. Jayaprakash, } \mathrm{P} \\
\text { and Pillai, } \mathrm{R}\end{array}$ & 2018 & $\begin{array}{l}\text { India Posts Putting Its Best Leg Forward: A Case on } \\
\text { ICT4D }\end{array}$ & $\begin{array}{l}\text { International Conference on } \\
\text { Information Resources } \\
\text { Management }\end{array}$ \\
\hline 20. Khera R. & 2017 & Impact of Aadhaar on welfare programmes & $\begin{array}{l}\text { Economic and Political } \\
\text { Weekly }\end{array}$ \\
\hline 21. & 2018 & The Aadhaar debate: Where are the sociologists? & $\begin{array}{l}\text { Contributions to Indian } \\
\text { Sociology }\end{array}$ \\
\hline $\begin{array}{l}\text { 22. Kotwal V., } \\
\text { Parsheera S., Kak } \\
\text { A. }\end{array}$ & 2017 & OPEN Data \& digital identity: Lessons for Aadhaar & $\begin{array}{l}\text { Proceedings of the } 2017 \text { ITU } \\
\text { Kaleidoscope Academic } \\
\text { Conference: Challenges for } \\
\text { a Data-Driven Society, ITU } \\
\text { K } 2017\end{array}$ \\
\hline $\begin{array}{l}\text { 23. Mali N.V., Avila- } \\
\text { Maravilla M.A. }\end{array}$ & 2018 & $\begin{array}{l}\text { Convergence or conflict? Digital identities vs. } \\
\text { citizenship rights: Case study of unique } \\
\text { identification number, Aadhaar, in India }\end{array}$ & $\begin{array}{l}\text { ACM International } \\
\text { Conference Proceeding } \\
\text { Series }\end{array}$ \\
\hline 24. Masiero S. & 2015 & Will the JAM trinity dismantle the PDS? & $\begin{array}{l}\text { Economic and Political } \\
\text { Weekly }\end{array}$ \\
\hline 25. Masiero $\mathrm{S}$. & 2016 & $\begin{array}{l}\text { Mapping and Explaining the Formation of } \\
\text { Beneficiary Perceptions in ICT4D }\end{array}$ & $\begin{array}{l}\text { Americas Conference on } \\
\text { Information Systems, }\end{array}$ \\
\hline 26. Masiero $\mathrm{S}$. & 2018 & $\begin{array}{l}\text { Explaining trust in large biometric infrastructures: A } \\
\text { critical realist case study of India's Aadhaar project }\end{array}$ & $\begin{array}{l}\text { Electronic Journal of } \\
\text { Information Systems in } \\
\text { Developing Countries }\end{array}$ \\
\hline 27. Masiero S., Das S. & 2019 & $\begin{array}{l}\text { Datafying anti-poverty programmes: implications } \\
\text { for data justice }\end{array}$ & $\begin{array}{l}\text { Information Communication } \\
\text { and Society }\end{array}$ \\
\hline $\begin{array}{ll}\text { 28. } & \text { Mir U.B., Kar } \\
\text { A.K., Dwivedi } \\
\text { Y.K., Gupta M.P., } \\
\text { Sharma R.S. } \\
\end{array}$ & 2019 & $\begin{array}{l}\text { Realizing digital identity in government: Prioritizing } \\
\text { design and implementation objectives for Aadhaar } \\
\text { in India }\end{array}$ & $\begin{array}{l}\text { Government Information } \\
\text { Quarterly }\end{array}$ \\
\hline $\begin{array}{l}\text { 29. Mukherjee A., } \\
\text { Sahay S. }\end{array}$ & 2019 & $\begin{array}{l}\text { Sinking under its own weight: Case of Aadhaar } \\
\text { mediated entitlements in India }\end{array}$ & $\begin{array}{l}\text { IFIP Advances in } \\
\text { Information and } \\
\text { Communication Technology }\end{array}$ \\
\hline $\begin{array}{l}\text { 30. Mukhopadhyay S., } \\
\text { Bouwman H., } \\
\text { Jaiswal M.P. }\end{array}$ & 2019 & $\begin{array}{l}\text { An open platform centric approach for scalable } \\
\text { government service delivery to the poor: The } \\
\text { Aadhaar case }\end{array}$ & $\begin{array}{l}\text { Government Information } \\
\text { Quarterly }\end{array}$ \\
\hline $\begin{array}{l}\text { 31. Mukunthan A., } \\
\text { Agarwal G. }\end{array}$ & 2019 & JAM: A digital, economic \& social revolution & $\begin{array}{l}\text { ACM International } \\
\text { Conference Proceeding } \\
\text { Series }\end{array}$ \\
\hline 32. Nair V. & 2018 & $\begin{array}{l}\text { An eye for an I: recording biometrics and } \\
\text { reconsidering identity in postcolonial India }\end{array}$ & Contemporary South Asia \\
\hline 33. Parikh K.S. & 2013 & Right to food and food grain policy & $\begin{array}{l}\text { Economic and Political } \\
\text { Weekly }\end{array}$ \\
\hline
\end{tabular}




\begin{tabular}{|c|c|c|c|}
\hline $\begin{array}{l}\text { 34. } \text { Patankar R., Vyas } \\
\text { S.K., Tyagi D. }\end{array}$ & 2017 & Achieving universal digital literacy for rural India & $\begin{array}{l}\text { ACM International } \\
\text { Conference Proceeding } \\
\text { Series }\end{array}$ \\
\hline 35. Rao U. & 2019 & $\begin{array}{l}\text { Population meets database: Aligning personal, } \\
\text { documentary and digital identity in Aadhaar- } \\
\text { enabled India }\end{array}$ & $\begin{array}{l}\text { South Asia: Journal of South } \\
\text { Asia Studies }\end{array}$ \\
\hline 36. Rao U., Nair V. & 2019 & Aadhaar: Governing with biometrics & $\begin{array}{l}\text { South Asia: Journal of South } \\
\text { Asia Studies }\end{array}$ \\
\hline 37. Rao, U & 2019 & $\begin{array}{l}\text { Response to 'The Aadhaar debate: Where are the } \\
\text { sociologists?' }\end{array}$ & $\begin{array}{l}\text { Contributions to Indian } \\
\text { Sociology }\end{array}$ \\
\hline $\begin{array}{l}\text { 38. Rawat P., Morris } \\
\text { J.C. }\end{array}$ & 2019 & $\begin{array}{l}\text { The Global and the Local: Tracing the Trajectory of } \\
\text { the Largest Biometric Identity Program }\end{array}$ & Politics and Policy \\
\hline 39. Satpathy T. & 2017 & The Aadhaar: "Evil" Embodied as Law & Health and Technology \\
\hline $\begin{array}{l}\text { 40. Seetharaman P., } \\
\text { Pant A. }\end{array}$ & 2018 & $\begin{array}{l}\text { Citizen's gain? Institutional logics and the making of } \\
\text { India's Aadhaar identity project }\end{array}$ & $\begin{array}{l}\text { International Conference on } \\
\text { Information Systems 2018, } \\
\text { ICIS } 2018\end{array}$ \\
\hline $\begin{array}{l}\text { 41. Sen A., Ghatak D., } \\
\text { Kumar K., } \\
\text { Khanuja G., } \\
\text { Bansal D., Gupta } \\
\text { M., Rekha K., } \\
\text { Bhogale S., } \\
\text { Trivedi P., Seth A. }\end{array}$ & 2019 & $\begin{array}{l}\text { Studying the discourse on economic policies in } \\
\text { India using mass media, social media, and the } \\
\text { parliamentary question hour data }\end{array}$ & $\begin{array}{l}\text { COMPASS } 2019 \text { - } \\
\text { Proceedings of the } 2019 \\
\text { Conference on Computing } \\
\text { and Sustainable Societies }\end{array}$ \\
\hline $\begin{array}{l}\text { 42. Sengupta D., } \\
\text { Shastri N. }\end{array}$ & 2019 & $\begin{array}{l}\text { Digital payments through PFMS - Facilitating } \\
\text { digital inclusion and accelerating transformation to } \\
\text { a 'Digital Economy' }\end{array}$ & $\begin{array}{l}\text { ACM International } \\
\text { Conference Proceeding } \\
\text { Series }\end{array}$ \\
\hline 43. Singh $\mathrm{P}$. & 2019 & $\begin{array}{l}\text { Aadhaar and data privacy: biometric identification } \\
\text { and anxieties of recognition in India }\end{array}$ & $\begin{array}{l}\text { Information Communication } \\
\text { and Society }\end{array}$ \\
\hline 44. Singh R. & 2019 & Give me a database and I will raise the Nation-state & $\begin{array}{l}\text { South Asia: Journal of South } \\
\text { Asia Studies }\end{array}$ \\
\hline $\begin{array}{l}\text { 45. Singh R., Jackson } \\
\text { S.J. }\end{array}$ & 2017 & $\begin{array}{l}\text { From margins to seams: Imbrication, inclusion, and } \\
\text { torque in the Aadhaar identification project }\end{array}$ & $\begin{array}{l}\text { Conference on Human } \\
\text { Factors in Computing } \\
\text { Systems - Proceedings }\end{array}$ \\
\hline 46. Sinha $\mathrm{S}$. & 2018 & $\begin{array}{l}\text { Gender digital divide in India: Impacting women's } \\
\text { participation in the labour market }\end{array}$ & $\begin{array}{l}\text { Reflecting on India's } \\
\text { Development: Employment, } \\
\text { Skill and Health }\end{array}$ \\
\hline 47. Sivamalai L. & 2013 & $\begin{array}{l}\text { Using the lens of "social construction of } \\
\text { technology" to understand the design and } \\
\text { implementation of Aadhaar (UID) project }\end{array}$ & $\begin{array}{l}\text { IFIP Advances in } \\
\text { Information and } \\
\text { Communication Technology }\end{array}$ \\
\hline $\begin{array}{l}\text { 48. Srivastava A.K., } \\
\text { Sharma S. }\end{array}$ & 2017 & $\begin{array}{l}\text { Social justice through Aadhaar: An e-policy } \\
\text { initiative }\end{array}$ & $\begin{array}{l}\text { Technology, Society and } \\
\text { Sustainability: Selected } \\
\text { Concepts, Issues and Cases }\end{array}$ \\
\hline
\end{tabular}

